The Geographical Journal of Nepal

Vol. 13: 143-166, 2020

Doi: http://doi.org/10.3126/gjn.v13i0.28156

Central Department of Geography,

Tribhuvan University, Kathmandu, Nepal

\title{
Pathways and magnitude of change and their drivers of public open space in Pokhara Metropolitan City, Nepal
}

\author{
Ramjee Prasad Pokharel ${ }^{1 *}$ and Narendra Raj Khanal ${ }^{2}$ \\ ${ }^{1}$ Department of Geography, Prithvi Narayan Campus, Pokhara, Nepal \\ ${ }^{2}$ Central Department of Geography, Kirtipur, Kathmandu, Nepal \\ *Corresponding Author: ramjeepp@gmail.com
}

Received: 25 November 2019; Accepted: 12 January 2020; Published: March 2020

\begin{abstract}
Public open space (POS), which is known as production space, is an integral part of an urban area. The pathways of change of $P O S$ are directly related to the urbanization process. Several factors play a vital role in creating an open space to satisfy peoples' physical and mental desires. This paper discusses the pathways and magnitude of change of POS and its drivers. This study is based on a detailed study of 32 sampled sites out of a total of 275 sites identified in Pokhara metropolitan city, and interviews with key informants in the concerned sites. The results show that there is no uniform trend in the change of open space. The area has remained constant in some sites whereas it has been decreased in some sites and also increased in some sites. Out of the total, 56.25 percent of patches remained constant in terms of area whereas 40.13 percent patches are decreased and increased in only 3.12 percent patches during the period between 1998 to 2018. There has been a net decrease of 24.652 hectors in the area in total. The increase of 3.12 percent attributed mainly to land pooling from individual ownership whereas the decrease is mainly due to the encroachment by individual people as well as for the construction of public infrastructure especially for expansion of the roads. The changes observed are not only limited to the change in the area but also the layout and the using pattern. Both the natural and the socio-economic factors including government policy are found responsible for such change. On the one hand, natural processes like sedimentation, landslides, floods, vegetation regeneration, cutting edge and on the other hand, government policies for the development of infrastructure facilities, rapid increase in urban area and consequent increase in land value, lack of awareness to the importance of open space among local people including local government are responsible for such change.
\end{abstract}

Keywords: Public open space; urbanization, pathways, driving factors; natural and socio-economic factors. 


\section{Introduction}

The landscape of urban open space is "an area, as perceived by people, whose character is the result of the action and interaction of natural and/or human factors" (Council of Europe, 2000). "Places in public space are not given but constructed by people, often on the basis of power relations, and this has significant consequences for individuals' sense of place" (Galic, 2017).

Public Open Space (POS) can be defined from different perspectives. Woolley (2003) and Thompsons (2002) have defined open spaces as the spaces in the city where cultural diversity intermingle with natural processes and conserve memory. Open space is also defined as the physical land and the water mass not covered by buildings, situated within the urban area (Gold,1980; Cranz, 1982). Urban open spaces are expected to function not as an isolated unit but as a vital part of the urban landscape with its own specific set of functions (Urban Task Force, 1999). It contributes to the quality of urban life in many ways so urban open spaces are an inseparable part of the urban landscape (Perovic and Folic, 2012). Open space in the city is a produced space (Lefebvre, 1991; Duff, 2010). Public spaces are such places which have public ownership and used for the benefits of the public without a profit motive and also easily assessable for the public for the recreational and refreshment purpose (UN Habitat, 2015). Public open space has free accessibility for the people which is outdoor space (Jacobs, 1961 and Madanipour, 1999). Successful public open space should promote psychological well-being and safety (Kalpan, 1985). Public open space is providing an informal and suitable for recreation (Whyte, 1985; Project for Public Space, 2000). In the physical dimension, the criteria of high quality public open space is the clear and easy access a movement system (Dansiworo, 1989; Carr, et al. 1992; Rivlin, 1994; Project for Public Open space, 2000; Ghel, 2002 and Nasution \& Zahrah, 2012). Public open space is space for politics, religious, commerce, sports, space for peaceful, coexistence and important encounter (Walzer, 1986). POS is a part of the urban landscape so its changes are often seen as a function of biophysical and socio-economic factors that are referred to as the driving factors of land-use change (Tunner II et al., 1990; Thomas, 2008). POS is also modified according to the natural process and socio-economic activities. "Public open space is one of the important urban environment elements which give a positive contribution to the quality of life" (Nasution $\&$ Zahrah, 2014). Most landscapes or urban space are affected by five major groups of driving factors which are named as socioeconomic, political, technological, natural, and cultural (Burgi, Hersperger, and Schneeberger, 2004). Urban green spaces are mosaics of natural and human-managed patches, and the driving factors for their change are multifold (Kong and Nakagoshi, 2005). The changing face of the public open space is an indicator of the changing social, economic and cultural face of the city (Villanueva, 
et al., 2015). This study has used diverse approaches to signify the magnitude of urban public open space change. Public space seems to be driven by the desire to ensure that spaces are safe, lucrative, predictable and, all in all (Galic, 2017). Human-human and human-nature re interactions in the POS which played a vital role in the sustainable environment in city life (Omar, Ibrahim, and Mohamad, 2015).

In the context of Nepal, a study of the POS of the Kathmandu city also shows the change in open space caused by different factors (Chitrakar, 2015). However, the processes of change and driving factors of POS in other cities in Nepal are poorly understood. Based on this context that this study in Pokhara Metropolitan City (PMC) was carried out with the objectives of identifying the pathways and quantifying the magnitude of change of POS and its driving factors of transformation.

\section{Study area:}

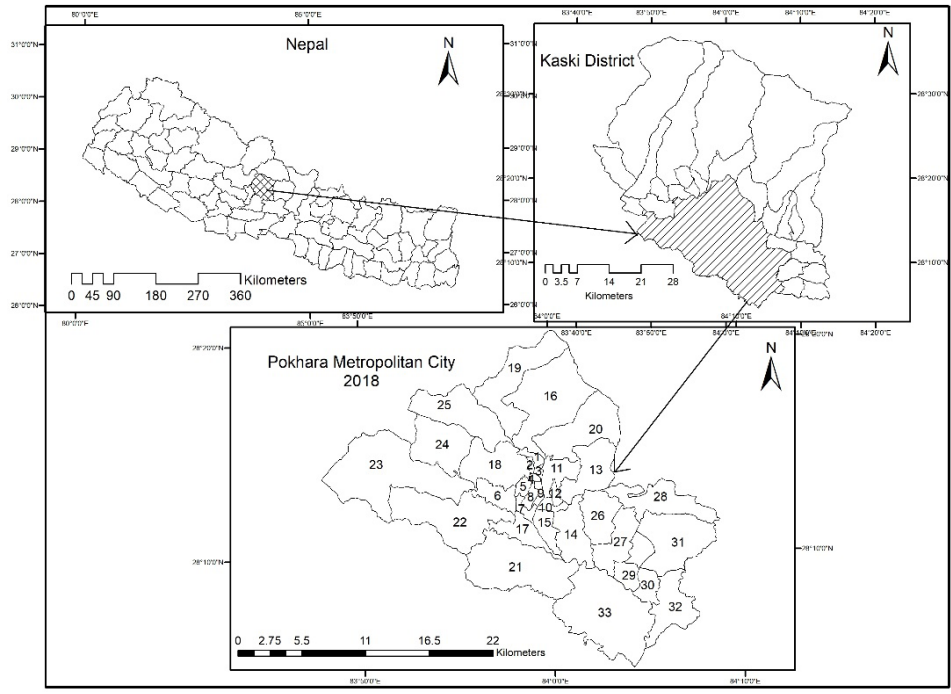

Figure 1: Location map of the study area

Sources: Topographical Maps $(1998,2017)$ scale 1:25000

Pokhara metropolitan city (PMC) is the utmost beautiful city located in the middle hills of Nepal. The elevation ranges from 505 meters at Kotre to 2650 meters at Armala above mean sea level. The total area of PMC is $464.24 \mathrm{~km}^{2}$ and which represents $23.01 \%$ area of the Kaski district and $0.31 \%$ area of the country. This metropolitan city is divided into 33 wards (Figure 1). The total number of households in the city is 81456 with a 
population of 402995 (CBS, 2011). This city is situated closely to the southern lap of Annapurna Himalayan Range.

It is well surrounded by beautiful green hills. There are 9 lakes, 10 caves, unique river gorges, several holy places, aesthetic viewpoints that have been playing a vital role to make the city gorgeous and ever memorable.

\section{Methods and materials}

This study is based on both quantitative and qualitative information. It is based on the procedure of the conventional approach to indicate change of micro-level landscape as an urban POS. At first, all the POS sites were listed as per the information given by ward offices of a metropolitan city. And, then existing sites were identified and mapped with the help of local resource persons. During the inventory survey, 275 patches of POS were found in the entire area of PMC. All the POS identified during the inventory survey were grouped on the basis of spatial configurations of patches into 32 sub typologies under eight typologies (Pokharel and Khanal, 2017).

Although, out of the total 275 sites, 32 sample sites were selected purposively based on sub typology. At least one site is taken from sub typology for a detailed study because it can represent a similar character of POS. The GPS device was used to collect existing spatial and attribute information of 32 sites.

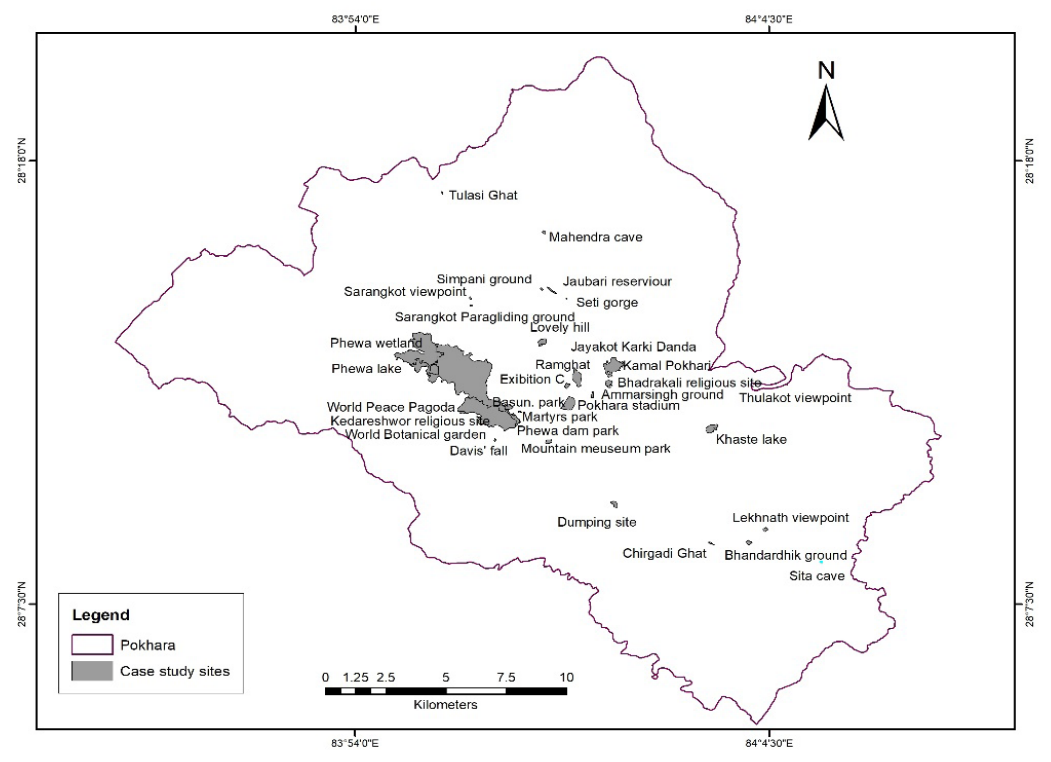

Figure 2: Spatial distribution of study sites 
Due to a lack of availability of spatial data of all the patches, the time series information for 8 patches were collected from the cadastral map (1975). Those sites were again surveyed by the researchers by using GPS survey (2018). After delineation of open space for other 7 sites were made using GPS survey, 4 patches from the cadastral survey and remaining other sites were prepared to map through the Google map. Further, the information on the pathways, magnitude, and drivers of change were collected through interviews with Key Informants (6).

All data were mapped with the help of ArcGIS software and analyzed. The information from Key Informants was recorded in Nepali script. It was translated and transcribed later. The spatial distribution of sampled POS is shown in figure 2. The patches of POS and their driving factors have been altered according to their natural characteristics. However, based on previous analytical review a research framework is designed (Chart 1). This framework shows different driving factors such as natural and anthropogenic causes that have been carried out in an attempt to identify existing POS and its pathways and magnitude and driving factors to change.

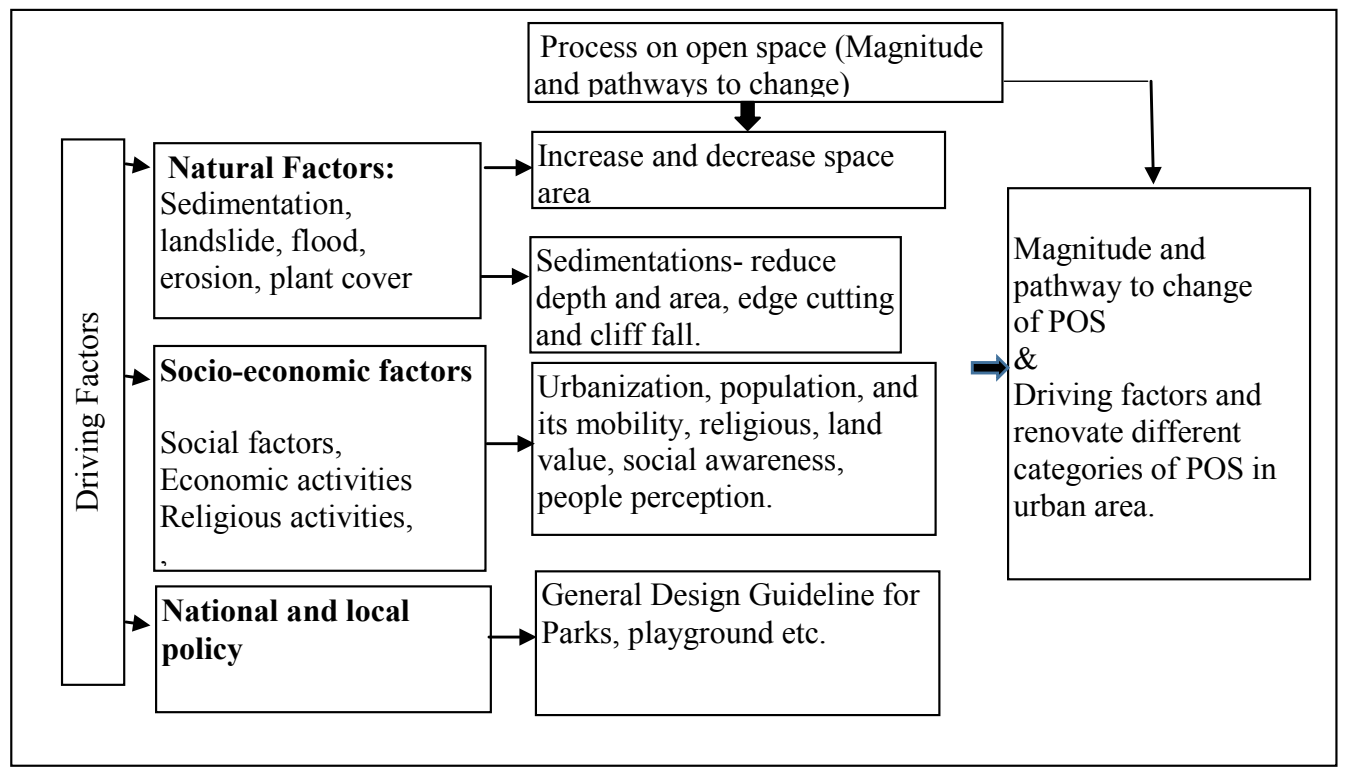

Chart 1: Pathways of change of public open space and its driving factors

Source: Adapted from Step 25: Thematic Concept: Green and Open Spaces edited by Dr. Isabel Wieshofer, Eva Prochazka, 2015 with slight modification.

The above chart describes the pathways, magnitude and driving factors of changing the process of open space based on nature and human beings. This study includes 
main and sub-factors such as social, religious, recreational, etc. as a pathway change of open space. Thus this study framework is more applicable to relevant pathways and magnitude of change and driving factors in Pokhara metropolitan city. The case study method has been adopted to identify driving factors and the pathway of change of POS. KII's interview and field book information are analyzed with the help of tables, maps, charts, and figures.

\section{Result and discussion}

\section{Pathways and magnitude of change}

The vacant strips of land owned by the government within the urban area have been recognized as present POS. Earlier these areas were known as Patan (open field) (Adhikari, 2004). Due to its dynamic nature and anthropogenic cause, some patches are reduced and some are increased in size. However, major changing pathways are reducing depth and area of water surface, river edge cutting and cliff fall, urbanization, population and its mobility, religions, land value, social awareness, people perception using design guideline and proper function, using pattern, and infrastructure development are major pathways to change the POS. Table 1 shows the pathways and magnitude of change in terms of area in the study sites.

Table 1: Public open space and their magnitude of change

\begin{tabular}{|c|c|c|c|c|c|c|}
\hline \multirow{2}{*}{ POS name } & \multicolumn{2}{|c|}{ The area in (Hectares) } & \multirow{2}{*}{$\begin{array}{c}\text { Change in } \\
\text { area } \\
\text { (Hectares) }\end{array}$} & \multirow{2}{*}{$\begin{array}{c}\text { Change } \\
\text { in } \\
\text { percent }\end{array}$} & \multirow{2}{*}{ Previous use } & \multirow{2}{*}{$\begin{array}{c}\text { Presen } \\
\text { use } \\
\text { (Types) }\end{array}$} \\
\hline & $\begin{array}{c}\text { Base year } \\
(1998)\end{array}$ & $\begin{array}{l}\text { Present year } \\
\quad(2018)\end{array}$ & & & & \\
\hline Basundhara park & $5.958 *$ & 5.958@@@ & 0 & 0 & Agriculture filed & \multirow{6}{*}{ Park } \\
\hline Lovely hill & $8.0906 * * *$ & 7.3746@@@ & -0.709 & -8.78 & Grazing land & \\
\hline Phewa dam park & $0.1845 * * *$ & 0.1591@@ & -0.033 & -18.14 & Barren land & \\
\hline Martyrs park & $0.8197 * * *$ & 0.7943@@@ & -0.029 & -3.49 & Grazing land & \\
\hline Mountain museum park & $3.3442 * * *$ & 3.3442@@@ & 0 & 0 & Agriculture & \\
\hline World Botanical Garden & $165.528 * * *$ & 165.528@@@ & 0 & 0 & Forest & \\
\hline
\end{tabular}


Ramjee Prasad Pokharel \& Narendra Raj Khanal / Pathways and magnitude... Vol. 13: 143-166, 2020

\begin{tabular}{|c|c|c|c|c|c|c|}
\hline Ammarsingh ground & $1.787^{*}$ & 1.684@@ & -0.103 & -5.76 & Barren land & \multirow{5}{*}{ Playground } \\
\hline Bhandardhik playground & $2.812 * * *$ & 2.657@@ & -0.155 & -5.51 & Barren land & \\
\hline Pokhara stadium & $12.923 *$ & 21.008@@@ & 8.085 & 62.57 & Grass weeds & \\
\hline Sarangkot recreation area & $0.5551 * * *$ & 0.5551@@ & 0 & 100 & Grass weeds & \\
\hline Simpani play ground & $0.864 * * *$ & 0.864@@ & 0 & 0 & Grazing land & \\
\hline Bhadrakali religious site & $7.112^{*}$ & 6.773@@@ & -0.339 & -4.77 & Religious site & \multirow{3}{*}{$\begin{array}{l}\text { Religious } \\
\text { site }\end{array}$} \\
\hline Kedareshwor religious site & $0.644 *$ & 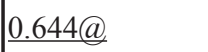 & 0 & 0 & Agriculture & \\
\hline World Peace Pagoda & $1.978 * * *$ & 1.903@@@ & -0.075 & -3.8 & Agriculture & \\
\hline Jaubari reservoir & $1.937 * * *$ & 1.937@@ & 0 & 0 & Barren land & \multirow{5}{*}{$\begin{array}{l}\text { Water } \\
\text { surface }\end{array}$} \\
\hline Kamal pokhari & $0.242 * *$ & 0.216@@@ & -0.026 & -10.74 & \multirow{3}{*}{ Water surface } & \\
\hline Khaste lake & $13.597 * *$ & 11.821@@@ & -1.776 & -13.06 & & \\
\hline Phewa lake & $447.551 * *$ & 434.089@@@ & -13.462 & -3.01 & & \\
\hline Davi's fall & $0.538^{*}$ & $0.538 @$ & 0 & 0 & Water fall & \\
\hline Kuile viewpoint (Lekhnath) & $2.278 * * *$ & 2.278@@@ & 0 & 0 & Barren land & \multirow{3}{*}{ Viewpoint } \\
\hline Sarangkot viewpoint area & $0.641 * * *$ & 0.641@@ & 0 & 0 & Agriculture & \\
\hline Thulakot viewpoint & $1.052 * * *$ & 1.052@@@ & 0 & 0 & Barren land & \\
\hline Mahendra cave & $1.211 *$ & 1.211@ & 0 & 0 & \multirow{2}{*}{ Cave } & \multirow{2}{*}{ Cave } \\
\hline Sita cave & $0.021 * * *$ & 0.021@@@ & 0 & 0 & & \\
\hline Seti gorge (KISingh bridge) & $0.203 * * *$ & 0.203@@@ & 0 & 0 & Barren & \multirow{4}{*}{ River strip } \\
\hline Chirgadi Ghat & $0.935 * * *$ & 0.935@@@ & 0 & 0 & \multirow{3}{*}{ River strip } & \\
\hline Ramghat & $21.473 * *$ & 19.556@@@ & -1.917 & -8.93 & & \\
\hline Tulasi Tara Ghat & $0.424 * * *$ & 0.424@@@ & 0 & 0 & & \\
\hline Dumping site & $4.473 * * *$ & 4.473@@@ & 0 & 0 & Barren land & \multirow{4}{*}{$\begin{array}{l}\text { Messy } \\
\text { space }\end{array}$} \\
\hline Jayakt (Karki Danda) & $38.116^{* *}$ & 36.335@@@ & -1.781 & -4.67 & Forest area & \\
\hline Phewa wetland & $173.996^{* *}$ & 161.109@@@ & -12.888 & -7.41 & Wet land & \\
\hline Pradarsani kendra & $2.674 *$ & 2.674@ & 0 & 2.67 & Barren & \\
\hline Total change & 923.403 & 898.751 & 24.652 & 2.67 & \multicolumn{2}{|c|}{ Per year reduce $=0.13 \%$} \\
\hline
\end{tabular}

Note: Base year and present time map sources:

*Cadastral map, 1974 Survey Office, Kaski

Survey Office, Kaski.

**Topographical map, 1998.

*** Google image, 1998.

(a) Cadastral map, 2017

@@GPS survey, 2018.

@@@ Google image, 2018. 
The decrease magnitude of change rate is 0.13 percent per year. Site specific magnitude of change is also shown in Figures 3 and 4.

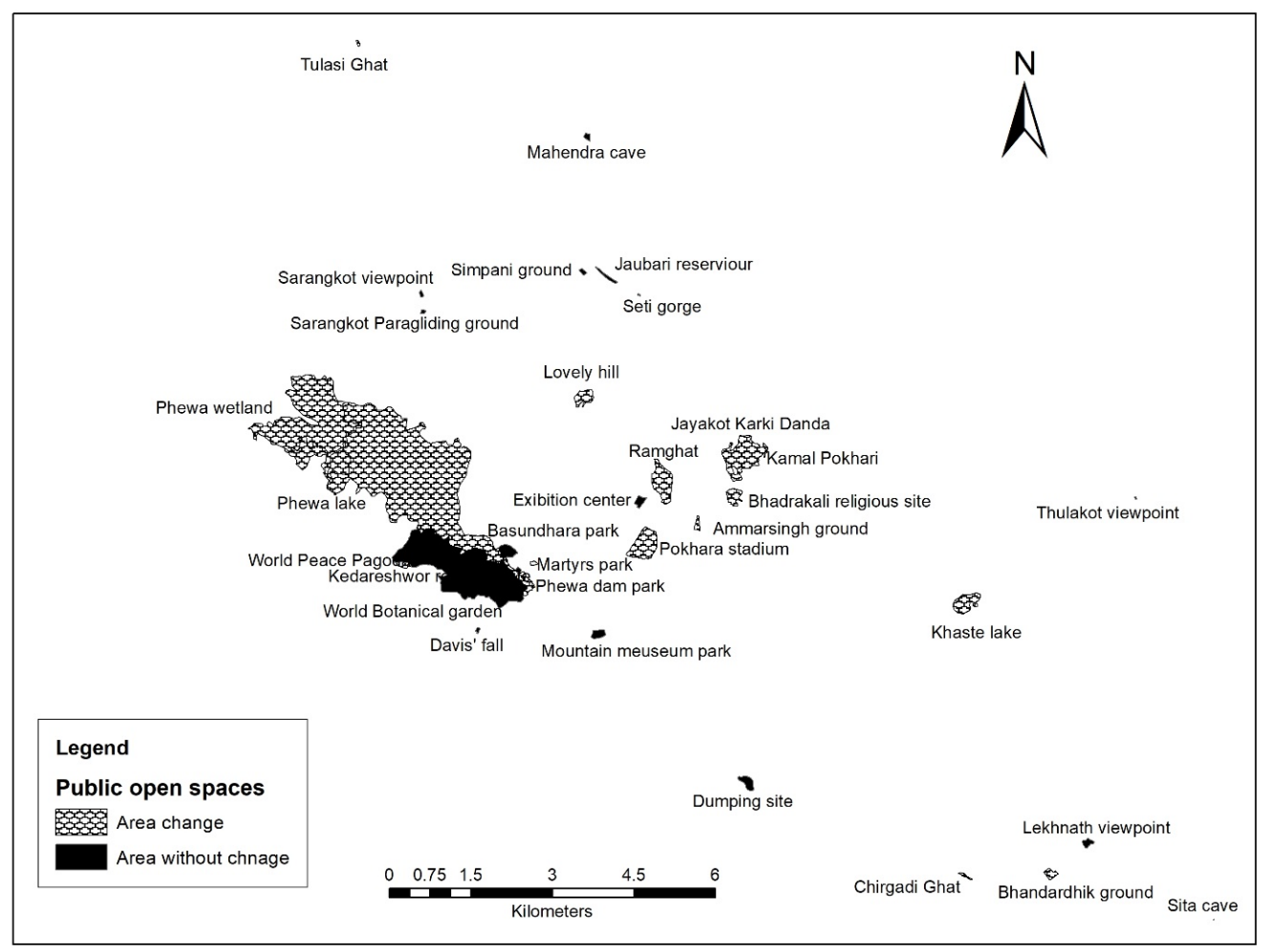

Figure 3: Magnitude of Change of selected POS (based on a study of 32 sites)
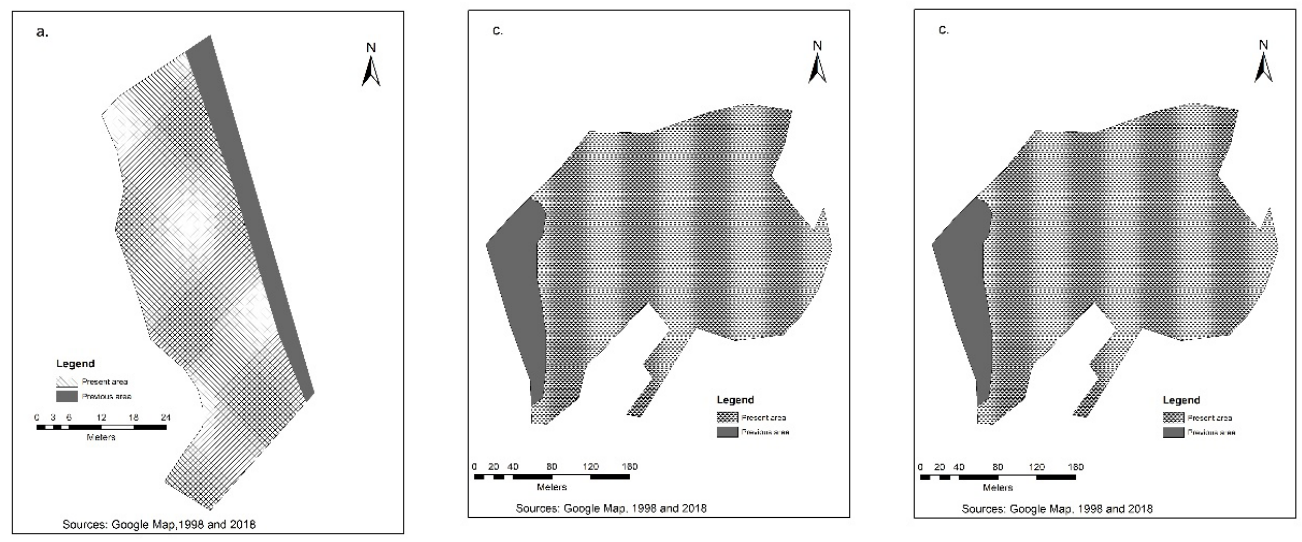

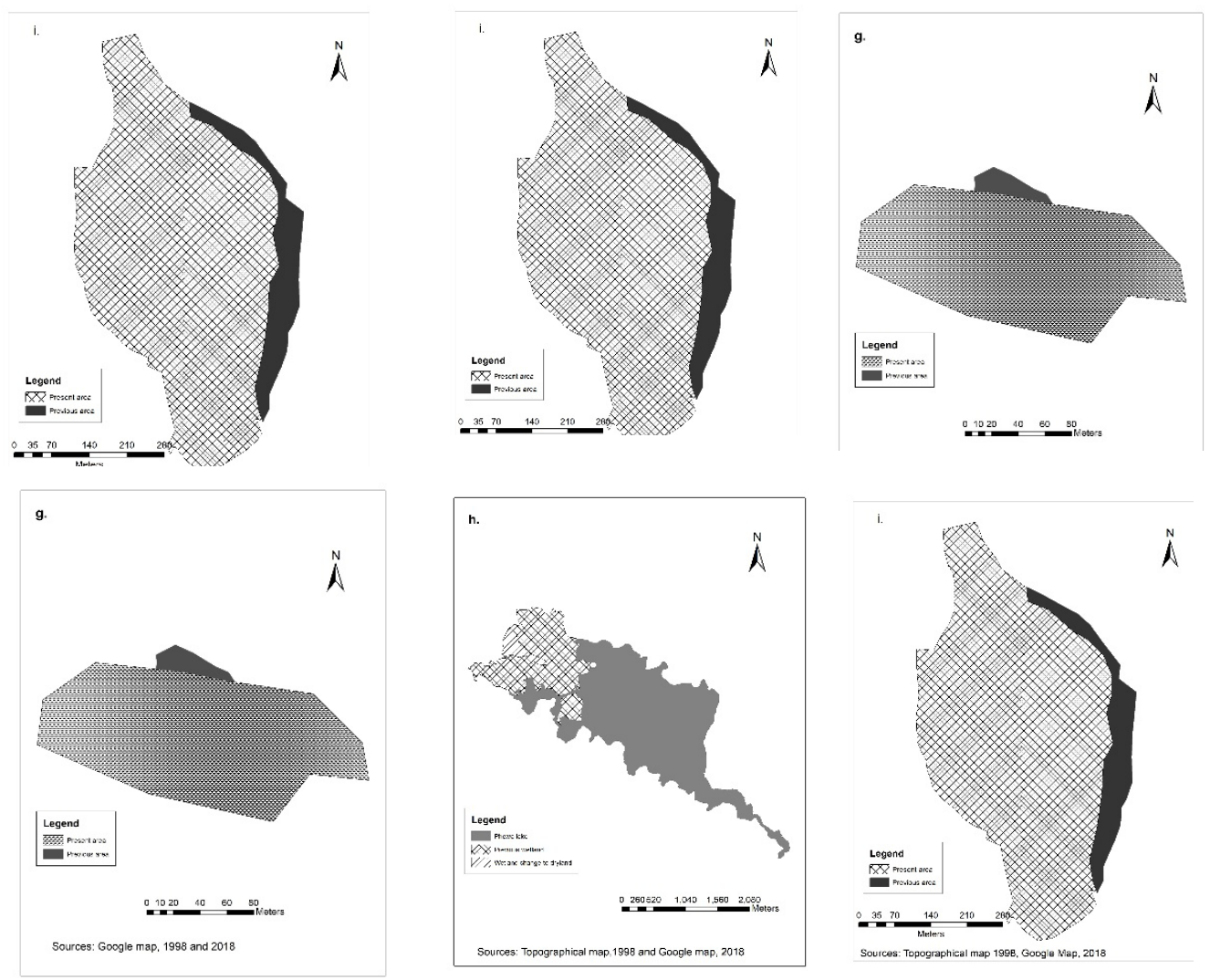

a. Phewa dam Park; b. Martyrs park; c. Lovely hill; d. Pokhara stadium; e. Bhandardhik playground; f. Amarsingh ground; g. World Peace Pagoda; h. Phewa lake and wetland; i. Ramghat. 


\section{Magnitude of change of POS}
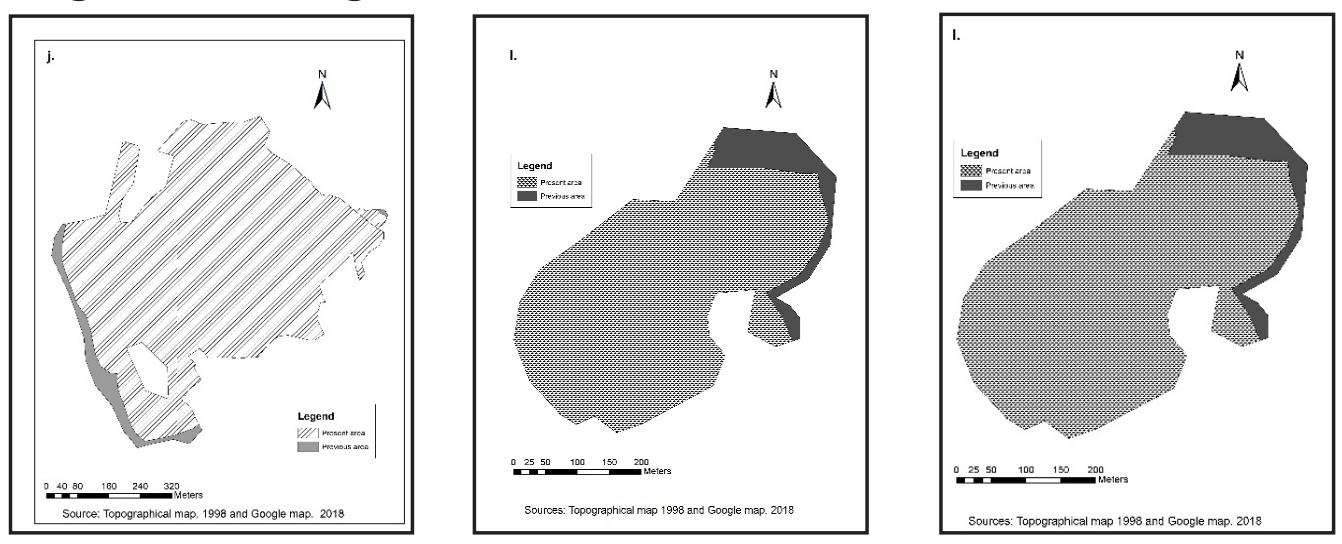

j. Jayakot and Kamal Pokahri; k. Bhadrakali religious site; 1. Khaste lake

Figure 4: Magnitude of change of POS in PMC (sample patches)

Except Pokhara stadium, the area of most patches has been reduced. Pokhara stadium is remarkably enlarged through the land pooling process from individual landowners by the government. Nearly, the area of 56.25 percent sites is remained constant, while the area of 3.12 percent sites has increased and the area of remaining 40.13 percent sites has been decreased in the study area. In the past, these areas were left idle. Some example of change is illustrated in figure 3 and 4 .

As the land value increased due to rapid population growth, local people used to utilize the open area for agriculture. Some of them were also used for grazing. At present 3.12 percent of sites which were previously used for grassland is used for stadium, 9.37 percent which was previously used for grazing and grassland is used for playground, viewpoint, and reservoir. The use of 56.25 percent of sites has not been changed. As suggested by KII 3.1 percent patches area is increased at present, but 28.2 percent patches area is reduced by individual encroachment. While 21.9 percent of patches are shrinking due to natural degradation. According to resource persons and cadastral mapping data among the patches, 40.13 percent patches are affected by encroachment with 24.652 hectares' area loss during the last 20 years.

\section{Use, service infrastructure, and its management}

The table 2 shows the use of open spaces. It is used for parks, playgrounds, religious activities, tourism activities and dumping of wastes. Nearly 18.75 percent sites are used as a park, 15.62 percent as a playground, 9.37 percent for a religious purpose, 37.5 
percent site is used for tourism development and 3.12 percent site for dumping. Out of the total of 32 sites, 56.25 percent sites are used for different purposes and the remaining 43.75 percent patches are left idle. However, the infrastructure development situation is among the patches which are shown in table 2 .

Table 2: Use and service infrastructure developed for open space

\begin{tabular}{|c|c|c|c|c|c|c|c|c|c|c|c|c|}
\hline \multirow[b]{2}{*}{$\begin{array}{l}\text { Typology } \\
\text { of POS }\end{array}$} & \multirow[b]{2}{*}{ Name of open space } & \multirow[b]{2}{*}{ 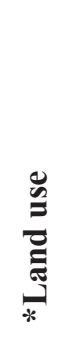 } & \multicolumn{10}{|c|}{ (a) Change by infrastructure development } \\
\hline & & & 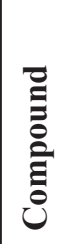 & $\frac{\mathscr{n}}{\tilde{e}}$ & 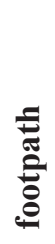 & 异 & : & 車 & 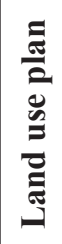 & 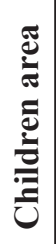 & 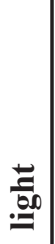 & 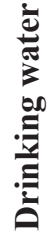 \\
\hline \multirow{6}{*}{ Park } & Basundhara park & $\sqrt{ }$ & $\sqrt{ }$ & $\mathrm{xx}$ & $\sqrt{ }$ & $\sqrt{ }$ & $\sqrt{ }$ & $\mathrm{Xx}$ & $\sqrt{ }$ & $\mathrm{xx}$ & $\sqrt{ }$ & $\mathrm{xx}$ \\
\hline & Lovely Hill & 0 & $\mathrm{Xx}$ & $\mathrm{xx}$ & $\mathrm{xx}$ & $\mathrm{xx}$ & $\mathrm{xx}$ & $\mathrm{Xx}$ & $\mathrm{xx}$ & $\mathrm{xx}$ & $\mathrm{xx}$ & $\mathrm{xx}$ \\
\hline & Dam side park & $\sqrt{ }$ & $\sqrt{ }$ & $\mathrm{xx}$ & $\sqrt{ }$ & $\sqrt{ }$ & $\mathrm{xx}$ & $\mathrm{Xx}$ & $\mathrm{xx}$ & $\mathrm{xx}$ & $x x$ & $\mathrm{XX}$ \\
\hline & Martyrs park & $\sqrt{ }$ & $\sqrt{ }$ & $\sqrt{ }$ & $\sqrt{ }$ & $\sqrt{ }$ & $\mathrm{xx}$ & $\mathrm{Xx}$ & $\sqrt{ }$ & $\mathrm{xx}$ & $\sqrt{ }$ & $\mathrm{xx}$ \\
\hline & Mountain museum park & $\sqrt{ }$ & $\sqrt{ }$ & $\mathrm{xx}$ & $\sqrt{ }$ & $\sqrt{ }$ & $\sqrt{ }$ & $\sqrt{ }$ & $\sqrt{ }$ & $\mathrm{xx}$ & $\sqrt{ }$ & $\sqrt{ }$ \\
\hline & World Botanical Garden & 0 & $\mathrm{Xx}$ & $\mathrm{xx}$ & $\sqrt{ }$ & $\mathrm{xx}$ & $\mathrm{xx}$ & $\mathrm{Xx}$ & $\mathrm{xx}$ & $\mathrm{xx}$ & $\mathrm{xx}$ & $\mathrm{xx}$ \\
\hline \multirow{5}{*}{ Playground } & Ammarsingh & ० & $\mathrm{Xx}$ & $\mathrm{xx}$ & $\mathrm{xx}$ & $\mathrm{xx}$ & $\mathrm{xx}$ & $\mathrm{Xx}$ & $\mathrm{xx}$ & $\mathrm{xx}$ & $\mathrm{xx}$ & $\mathrm{xx}$ \\
\hline & Bhandardhik & $\sqrt{ }$ & $\mathrm{Xx}$ & $\mathrm{xx}$ & $\mathrm{xx}$ & $\mathrm{xx}$ & $\mathrm{xx}$ & $\mathrm{Xx}$ & $\mathrm{xx}$ & $\mathrm{xx}$ & $\mathrm{xx}$ & $\mathrm{xx}$ \\
\hline & Pokhara stadium & $\sqrt{ }$ & $\sqrt{ }$ & $\sqrt{ }$ & $\sqrt{ }$ & $\sqrt{ }$ & $\sqrt{ }$ & $\sqrt{ }$ & $\mathrm{xx}$ & $\mathrm{xx}$ & $\sqrt{ }$ & $\sqrt{ }$ \\
\hline & Sarangkot paragliding site & $\sqrt{ }$ & $\mathrm{Xx}$ & $\mathrm{xx}$ & $\mathrm{xx}$ & $\mathrm{xx}$ & $\mathrm{xx}$ & $\mathrm{Xx}$ & $\mathrm{xx}$ & $\mathrm{xx}$ & $\mathrm{xx}$ & $\mathrm{xx}$ \\
\hline & Simpani Play ground & ० & $\mathrm{Xx}$ & $\mathrm{xx}$ & $\mathrm{xx}$ & $\sqrt{ }$ & $\mathrm{xx}$ & $\mathrm{Xx}$ & $\mathrm{xx}$ & $\mathrm{xx}$ & $\mathrm{xx}$ & $\mathrm{xx}$ \\
\hline \multirow{3}{*}{ Religious } & Bhadrakali religious site & $\sqrt{ }$ & $\sqrt{ }$ & $\sqrt{ }$ & $\sqrt{ }$ & $\sqrt{ }$ & $\sqrt{ }$ & $\mathrm{Xx}$ & $\sqrt{ }$ & $\sqrt{ }$ & $\sqrt{ }$ & $\sqrt{ }$ \\
\hline & Kedareshwor religious place & $\bullet$ & $\sqrt{ }$ & $\sqrt{ }$ & $\sqrt{ }$ & $\sqrt{ }$ & $\sqrt{ }$ & $\mathrm{Xx}$ & $\sqrt{ }$ & $\mathrm{xx}$ & $\sqrt{ }$ & $\sqrt{ }$ \\
\hline & World Peace Pagoda & $\sqrt{ }$ & $\sqrt{ }$ & $\sqrt{ }$ & $\sqrt{ }$ & $\sqrt{ }$ & $\sqrt{ }$ & $\sqrt{ }$ & $\sqrt{ }$ & $\sqrt{ }$ & $\sqrt{ }$ & $\sqrt{ }$ \\
\hline \multirow{5}{*}{$\begin{array}{l}\text { Water } \\
\text { surface }\end{array}$} & Jaubari Reservoir & ० & $\mathrm{Xx}$ & $\mathrm{xx}$ & $\mathrm{xx}$ & $\mathrm{xx}$ & $\mathrm{xx}$ & $\mathrm{Xx}$ & $\mathrm{xx}$ & $\mathrm{xx}$ & $\sqrt{ }$ & $\mathrm{xx}$ \\
\hline & Kamal Pokhari & 0 & $\sqrt{ }$ & $\sqrt{ }$ & $\sqrt{ }$ & $\sqrt{ }$ & $\mathrm{xx}$ & $\mathrm{Xx}$ & $\mathrm{xx}$ & $\mathrm{xx}$ & $\mathrm{xx}$ & $\mathrm{xx}$ \\
\hline & Khaste lake & o & $\mathrm{Xx}$ & $\sqrt{ }$ & $\sqrt{ }$ & $\sqrt{ }$ & $\mathrm{xx}$ & $\mathrm{Xx}$ & $\mathrm{xx}$ & $\mathrm{xx}$ & $\mathrm{xx}$ & $\mathrm{xx}$ \\
\hline & Davi's falls & $\sqrt{ }$ & $\sqrt{ }$ & $\sqrt{ }$ & $\sqrt{ }$ & $\sqrt{ }$ & $\sqrt{ }$ & $\mathrm{Xx}$ & $\sqrt{ }$ & $\mathrm{xx}$ & $\sqrt{ }$ & $\sqrt{ }$ \\
\hline & Phewa lake & O & $\mathrm{Xx}$ & $\sqrt{ }$ & $\sqrt{ }$ & $\sqrt{ }$ & $\sqrt{ }$ & $\sqrt{ }$ & $\sqrt{ }$ & $\mathrm{xx}$ & $\sqrt{ }$ & $\sqrt{ }$ \\
\hline \multirow{3}{*}{ Viewpoints } & Kuile viewpoint & 0 & $\mathrm{Xx}$ & $\mathrm{xx}$ & $\sqrt{ }$ & $\mathrm{xx}$ & $\mathrm{xx}$ & $\mathrm{Xx}$ & $\mathrm{xx}$ & $\mathrm{xx}$ & $\mathrm{xx}$ & $\mathrm{xx}$ \\
\hline & Sarangkot viewpoint & $\sqrt{ }$ & $\mathrm{Xx}$ & $\sqrt{ }$ & $\sqrt{ }$ & $\sqrt{ }$ & $\sqrt{ }$ & $\sqrt{ }$ & $\mathrm{xx}$ & $\mathrm{xx}$ & $\sqrt{ }$ & $\sqrt{ }$ \\
\hline & Thulakot viewpoint & 0 & $\mathrm{Xx}$ & $\sqrt{ }$ & $\mathrm{xx}$ & $\sqrt{ }$ & $\sqrt{ }$ & $\mathrm{Xx}$ & $\mathrm{xx}$ & $\mathrm{xx}$ & $\mathrm{xx}$ & $\sqrt{ }$ \\
\hline \multirow{2}{*}{ Cave } & Mahendra cave & $\sqrt{ }$ & $\sqrt{ }$ & $\sqrt{ }$ & $\sqrt{ }$ & $\sqrt{ }$ & $\sqrt{ }$ & $\sqrt{ }$ & $\sqrt{ }$ & $\mathrm{xx}$ & $\sqrt{ }$ & $\sqrt{ }$ \\
\hline & Sita Cave & 0 & $\mathrm{Xx}$ & $\mathrm{xx}$ & $\mathrm{xx}$ & $\mathrm{xx}$ & $\mathrm{xx}$ & $\mathrm{Xx}$ & $\mathrm{xx}$ & $\mathrm{xx}$ & $\mathrm{xx}$ & $\mathrm{xx}$ \\
\hline
\end{tabular}




\begin{tabular}{|c|c|c|c|c|c|c|c|c|c|c|c|c|}
\hline \multirow{4}{*}{$\begin{array}{l}\text { River strip } \\
\text { site }\end{array}$} & Seti Gorge & $\sqrt{ }$ & $\sqrt{ }$ & $\mathrm{xx}$ & $\sqrt{ }$ & $\sqrt{ }$ & $\sqrt{ }$ & $\mathrm{Xx}$ & $\sqrt{ }$ & $\mathrm{xx}$ & $\mathrm{xx}$ & $\mathrm{xx}$ \\
\hline & Chirgadi Ghat & 0 & $\mathrm{Xx}$ & $\mathrm{xx}$ & $\mathrm{xx}$ & $\mathrm{xx}$ & $\mathrm{xx}$ & $\mathrm{Xx}$ & $\mathrm{xx}$ & $\mathrm{xx}$ & $\mathrm{xx}$ & $\mathrm{xx}$ \\
\hline & Ramghat & 0 & $\mathrm{Xx}$ & $\mathrm{xx}$ & $\mathrm{xx}$ & $\mathrm{xx}$ & $\mathrm{xx}$ & $\mathrm{Xx}$ & $\mathrm{xx}$ & $\mathrm{xx}$ & $\mathrm{xx}$ & $\mathrm{xx}$ \\
\hline & Tulasi Tara Ghat & 0 & $\mathrm{Xx}$ & $\sqrt{ }$ & $\mathrm{xx}$ & $\mathrm{xx}$ & $\mathrm{xx}$ & $\mathrm{Xx}$ & $\mathrm{xx}$ & $\mathrm{xx}$ & $\mathrm{xx}$ & $\mathrm{xx}$ \\
\hline \multirow{4}{*}{$\begin{array}{l}\text { Massy } \\
\text { space }\end{array}$} & Dumping site & 0 & $\mathrm{xx}$ & $\mathrm{xx}$ & $\mathrm{xx}$ & $\mathrm{xx}$ & $\mathrm{xx}$ & $\mathrm{Xx}$ & $\mathrm{xx}$ & $\mathrm{xx}$ & $\mathrm{xx}$ & $\mathrm{xx}$ \\
\hline & Jayakot, Karki Danda & $\sqrt{ }$ & $\mathrm{xx}$ & $\sqrt{ }$ & $\mathrm{xx}$ & $\sqrt{ }$ & $\sqrt{ }$ & $\sqrt{ }$ & $\mathrm{Xx}$ & $\sqrt{ }$ & $\mathrm{xx}$ & $\sqrt{ }$ \\
\hline & Phewa wetland & 0 & $\mathrm{Xx}$ & $\mathrm{xx}$ & $\mathrm{xx}$ & $\mathrm{xx}$ & $\mathrm{xx}$ & $\mathrm{Xx}$ & $\mathrm{xx}$ & $\mathrm{xx}$ & $\mathrm{xx}$ & $\mathrm{xx}$ \\
\hline & Pradarsani Kendra & $\sqrt{ }$ & $\sqrt{ }$ & $\sqrt{ }$ & $\sqrt{ }$ & $\mathrm{xx}$ & $\mathrm{xx}$ & $\mathrm{Xx}$ & $\mathrm{XX}$ & $\mathrm{xx}$ & $\mathrm{Xx}$ & $\mathrm{xx}$ \\
\hline
\end{tabular}

* Open space with more building occupancy $=\bullet$, Open space being utilized for different purposes $=$ ?,

Open space left idle $=0$

$@$ Infrastructure development situation: yes $=\sqrt{ }$, no $=\mathrm{xx}$

Source: KII and field observation, 2018

The Table 2 shows that the infrastructure development situation among the patches is different. Among the patches, only about 40.63 percent have been compounded at present while 46.88 percent patches have shed. Similarly, 56.25 percent of patches of POS have got footpath and benches. Among the patches only 9.37 percent have managed children playing site.

The pathways to change in POS are the result of various design and effort of stakeholders which are currently developed in different features with the basis of particular characteristics of patches. The provision of service infrastructure plays a vital role to increase popularity and visitors' attraction towards the site. The POS are being changed in different ways. However, the changing pattern is depending on the spatial configuration of patches, using and management practices, protection from encroachment, and community decision along with government policy. 
Table 3: Characteristics of patches and pathways to change of patches

\begin{tabular}{|l|l|l|l|}
\hline Characteristics & Attributes & Number & Percent \\
\hline \multirow{4}{*}{$\begin{array}{l}\text { Landscape } \\
\text { development }\end{array}$} & Gardening & 11 & 34.4 \\
\cline { 2 - 4 } & Basic foundation & 12 & 37.5 \\
\cline { 2 - 4 } & Vegetation / plantation & 4 & 12.5 \\
\cline { 2 - 4 } & Security & 17 & 53.1 \\
\hline \multirow{4}{*}{$\begin{array}{l}\text { Manctional use } \\
\text { development }\end{array}$} & Multiple-use & 12 & 37.5 \\
\cline { 2 - 4 } & Social interaction & 10 & 31.3 \\
\cline { 2 - 4 } & Spiritual belief & 3 & 9.37 \\
\cline { 2 - 4 } & Single function (picnic, sight seen etc.) & 7 & 21.9 \\
\hline \multirow{4}{*}{ Encroachment } & Federal government & 6 & 18.8 \\
\cline { 2 - 4 } & Local government & 21 & 65.6 \\
\cline { 2 - 4 } & Community & 5 & 15.6 \\
\cline { 2 - 4 } & Public & 7 & 21.8 \\
\cline { 2 - 4 } & Individual & 9 & 28.2 \\
\cline { 2 - 4 } & Eo change & 15 & 46.9 \\
\cline { 2 - 4 } lnvolveme area & 1 & 3.1 \\
\hline \multirow{3}{*}{ local people } & Protection & 3 & 9.4 \\
\cline { 2 - 4 } & Infrastructure development & 6 & 18.8 \\
\cline { 2 - 4 } & Management & 8 & 25.0 \\
\cline { 2 - 4 } & No notable change & 15 & 46.9 \\
\hline
\end{tabular}

Source: Field study, 2018.

The table 3 shows that the internal side of POS has been changed for different purposes. However, 65.6 percent of patches are changed according to stakeholder and local land use policy. While 9.37 percent of patches are changed by spiritual activities and managed for religious activities. As suggested by KII there is no border and it is not separately mentioned in the cadastral map boundary also.

\section{Drivers of change}

The patches have been unremittingly changed by natural and socio-economic factors (Tunner II et al., 1990). The patches are changed depending on the nature of a place, availability of area, the interest of the local community and government policy. Some patches of the park, playground, religious sites have also become the main space to provide an opportunity for restoration after a catastrophic disaster. The driving factors of POS are briefly described below: 


\section{Natural Factors}

The natural landscape of POS patches has several forms. The land cover of POS consists of vegetation, bare land, sandy or rocky surface. But it does not remain the same forever because of various natural factors operating on it. The public open space in the metropolitan area has changed due to different biophysical processes such as soil erosion, sedimentation, landslide, flood, riverbank cutting, vegetation succession, etc. Some of the open spaces are located along the river channel and they are affected by the flood, river bank cutting, and siltation. Some are located in the hilly area and those are affected by denudation processes such as erosion and landslides. Similarly, some barren patches of POS are changed into greenery as a result of plantation and protection activities. Similarly, the lake area has been changed due to accelerated siltation. Table 4 and figure 2 show the number of sites affected due to natural factors and their consequences.

Table 4: Number of open spaces and its area affected by natural factors

\begin{tabular}{|c|c|c|c|c|}
\hline Natural factors & $\begin{array}{c}\text { Number } \\
\text { of sites }\end{array}$ & \begin{tabular}{|c|} 
Affected patches \\
area $(\mathbf{H})$ \\
\end{tabular} & Consequences & Examples \\
\hline Sedimentation & 6 & 628.727 & $\begin{array}{l}\text { Siltation from flood and } \\
\text { debris deposits resulted in a } \\
\text { decrease in area and depth }\end{array}$ & $\begin{array}{l}\text { Jaubari, Kamal Pokhari, Khaste lake, } \\
\text { Phewa lake, Phewa wetland, Ramghat }\end{array}$ \\
\hline Landslide & 2 & 2.544 & $\begin{array}{l}\text { Landslides damaged } \\
\text { the landscape and } \\
\text { infrastructure and } \\
\text { increased hazard and } \\
\text { disaster risk }\end{array}$ & $\begin{array}{l}\text { World Peace Pagoda, A } 20 \text { meters long } \\
\text { and } 10 \text { meters wide landslide occurred in } \\
\text { the north side near world peace pagoda } \\
\text { area, Sarangkot viewpoint }\end{array}$ \\
\hline Flood & 1 & 0.864 & $\begin{array}{l}\text { The flood destroyed the } \\
\text { land reducing the area }\end{array}$ & $\begin{array}{l}\text { Simpani playground. The flood of Seti } \\
\text { river which destroyed some parts }\end{array}$ \\
\hline $\begin{array}{l}\text { Riverbank } \\
\text { cutting }\end{array}$ & 3 & 1.562 & $\begin{array}{l}\text { Reduction in the area to } \\
\text { be utilized }\end{array}$ & $\begin{array}{l}\text { Chirgadi Ghat, Tulasi Tara Ghat and Seti } \\
\text { gorge }\end{array}$ \\
\hline Erosion & 1 & 7.375 & $\begin{array}{l}\text { The scenic beauty of } \\
\text { landscape is shrinking } \\
\text { due to erosion }\end{array}$ & Lovely hill \\
\hline $\begin{array}{l}\text { Natural growth } \\
\text { of vegetation }\end{array}$ & 4 & 210.914 & $\begin{array}{l}\text { The scenic beauties of } \\
\text { open space increased }\end{array}$ & $\begin{array}{l}\text { World botanical garden, Bhadrakali, Kuile } \\
\text { viewpoint, Jayakot }\end{array}$ \\
\hline $\begin{array}{l}\text { No change } \\
\text { from natural } \\
\text { processes }\end{array}$ & 15 & 46.765 & $\begin{array}{l}\text { The area and the scenic } \\
\text { value remained constant }\end{array}$ & $\begin{array}{l}\text { Basundhara Park, Dam side, Davis' } \\
\text { fall, Martyrs park, Mountain museum, } \\
\text { Ammarsingh, Bhandardhik, Pokhara } \\
\text { stadium, Sarangkot recreation area, } \\
\text { Kedareshwor, Thulakot Mahendra cave, } \\
\text { Sita Cave, Dumping site, Pradarsni } \\
\text { Kendra }\end{array}$ \\
\hline Total & 32 & 898.751 & & \\
\hline
\end{tabular}

Source: Field study 2018. 


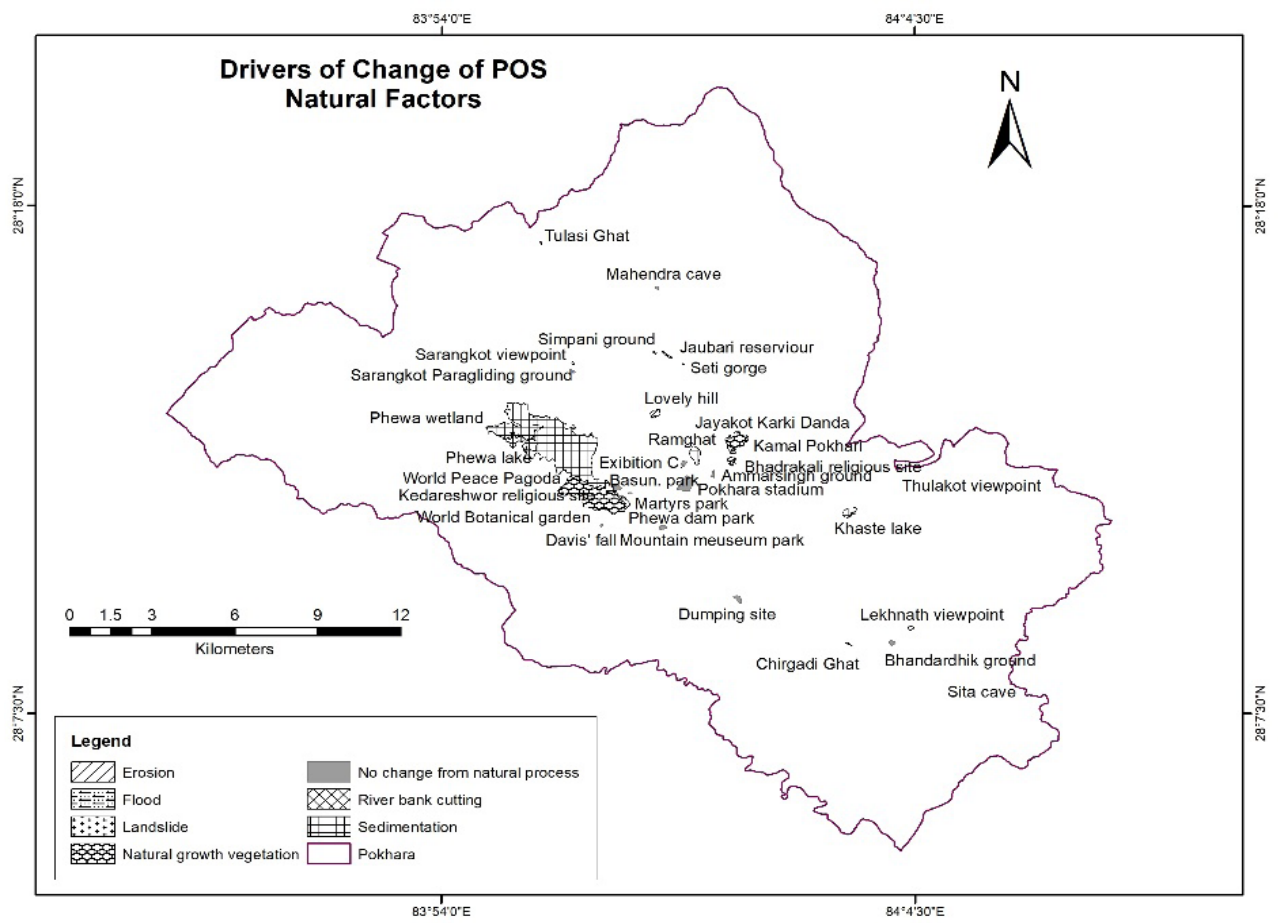

Figure 6: Natural factors to change the POS

During the field study, it was found that the headward side of Phewa lake was altered by siltation from Harpan river which resulted to reduce water surface area and increase wetland. Similarly, the Khaste lake area was shrinking by landslide that occurred 20 years before. Famous World Peace Pagoda is also at high risk due to huge landslides that occurred before four years at the northern side of this premises. The depositional valley of Pokhara formed by glaciofluvial process (Gurung,1965), it is highly susceptible to riverbank cutting. Similarly, landslides along its course have formed certain portions of edge like Ramghat, Chirgadi Ghat, Tulasi Tara Ghat edge left as an uninhabited open space. Similarly, 0.17 percent (table 1) area occupied by caves is gradually being changed by landslide, flood, and edge cutting as a natural process. 


\section{Social factors}

The public land area is changed by several causes. Because of increased public awareness for the need for open space, public open land is found to be used as a POS. The drivers of change as reported by one of the key informants are presented in Box 1 .

Box 1: Response of Key Informant

The land owned by the government was originally registered in the name of the person who is associated with the state and so-called clever person in society. Such places were not encroached upon after being compounded as a POS but the vacant public land has encroached at several sites in PMC like Simpani, Lamatahara, Gharipatan, near lovely hill, Sainik Basti, and Seti river corridor by squatters. There is a need to have in-depth study and mapping of government land scientifically. The riverbanks and water surface area can be encroached before government survey and construction of boundary in the existing POS'

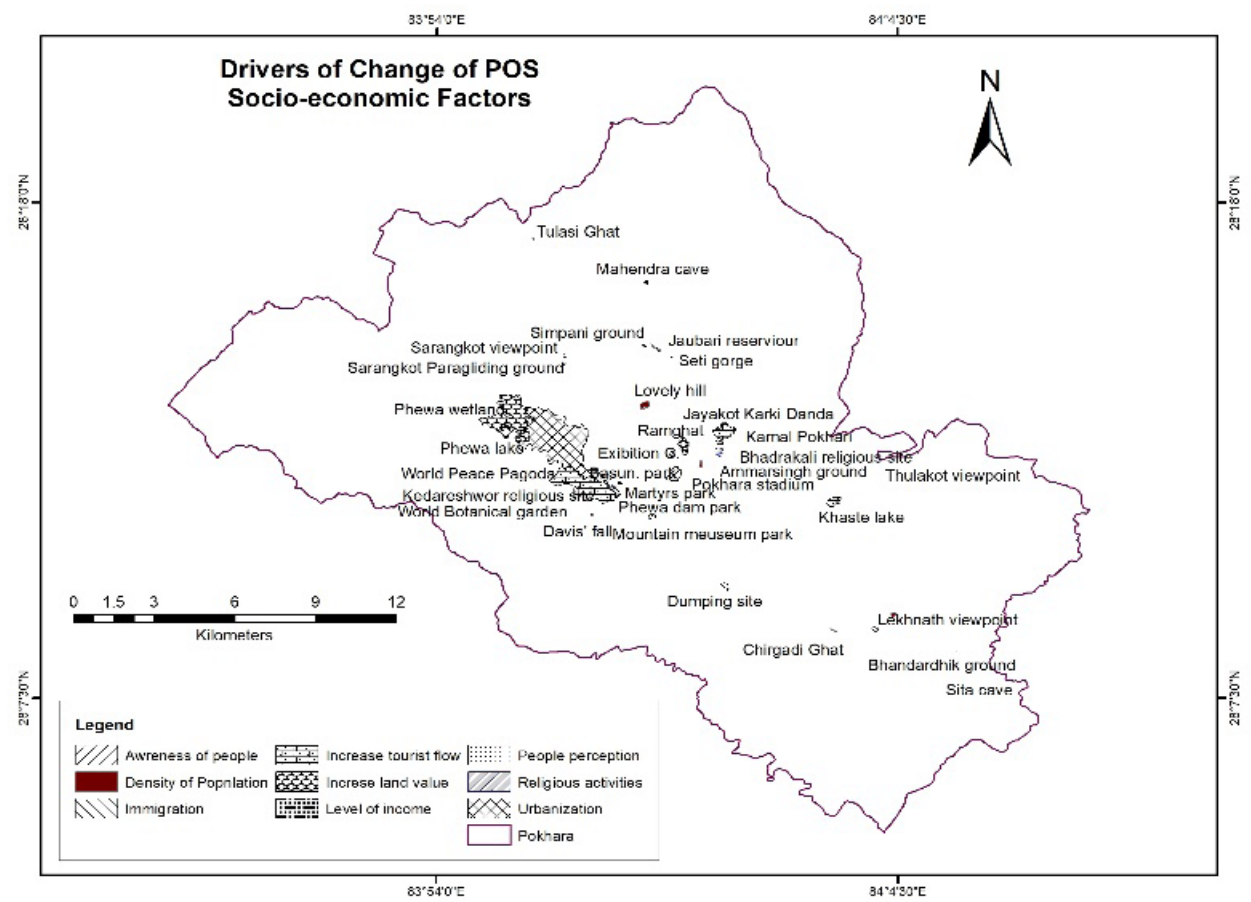

Figure 7: Socio-economic factors to change the POS

According to Adhikari (2004), public land nearby their private land has been made private in the name of Shoryani (the public land encroached by individual) and later 
it is registered in the name of the previous area of public land. Based on the empirical expression of the KII and present field observation, the fact is that the river strip, surrounding area of lakes and wetland areas were changed by natural process and human activities too. Some sites of urban open space are popular for recreational and spiritual activities. These sites are used for social as well as religious activities. Community gathering, various recreational activities, different outdoor games, political activities, business practices, etc. are promoted to the socialization of urbanities by POS.

Similarly, some patches are used as religious purposes. Due to its spiritual attraction and cognitive perception of visitors, the vacant area is used to establish a religious site which changes the condition of POS. However, various causes like urbanization process (roadside patches), land market or real state (Simpani, Ramghat area) architecture design inside the patches (World Peace Pagoda), land use planning (Mahendra cave), road accessibility (Sarangkot viewpoint) national and local government policy Basundhara park, world botanical garden), etc. play a significant role for temporal change of POS.

However, neighborhoods POS or urban core area is more valuable and people try to make it attractive and environmentally sound with their various activities. Similarly, naturally attractive sites are visited by more visitors. So local people have modified the internal layout and have developed service infrastructure according to the needs of visitors by constructing infrastructure, for example, World Peace Pagoda, David's falls, Mahendra cave, Seti gorge site etc. have been managed and decorated by local people as well communities. The infrastructure development process depends on different pathways. The initial stage of urban growth can be defined by scattered settlements and less valuable land but due to rapid urban growth, the POS patches have raised their value. However, land cover change of POS appears from natural sites to cultural space in various ways. Table 5 shows the social driving factors of the change of POS in the study area.

Table 5: Social factors

\begin{tabular}{|c|c|c|c|}
\hline Social process & \begin{tabular}{|l} 
Number \\
of \\
patches
\end{tabular} & Consequences & *Patches name \\
\hline 1. $\begin{array}{l}\text { Accelerated } \\
\text { Urbanization }\end{array}$ & 7 & $\begin{array}{l}\text { Decrease in area and } \\
\text { quality of open space } \\
\text { due to construction road, } \\
\text { encroachment for temporary } \\
\text { business, dumping urban } \\
\text { waste, business prompt. }\end{array}$ & $\begin{array}{l}\text { Basundhara park, Dam } \\
\text { side park, Bhandardhik } \\
\text { playground, Pokhara } \\
\text { stadium, Phewa } \\
\text { lake, Dumping site, } \\
\text { Pradarsni Kendra } \\
\end{array}$ \\
\hline
\end{tabular}




\begin{tabular}{|c|c|c|c|c|}
\hline 2. & $\begin{array}{l}\text { Density of } \\
\text { population }\end{array}$ & 5 & $\begin{array}{l}\text { Encroached public land and } \\
\text { construct individual house, } \\
\text { use vulnerable area (river } \\
\text { strip) }\end{array}$ & $\begin{array}{l}\text { Lovely hill, } \\
\text { Ammarsingh, Kuile } \\
\text { viewpoint, Chirgadi } \\
\text { Ghat, Tulasi Tara Ghat } \\
\end{array}$ \\
\hline 3. & Immigration & 1 & $\begin{array}{l}\text { They try to manage the } \\
\text { playground for their children }\end{array}$ & Simpani Play ground \\
\hline 4. & $\begin{array}{l}\text { Increased } \\
\text { religious } \\
\text { activities }\end{array}$ & 2 & Increased attractiveness. & $\begin{array}{l}\text { Bhadrakali religious } \\
\text { site, Kedareshwor } \\
\text { religious site } \\
\end{array}$ \\
\hline 5. & $\begin{array}{l}\text { Level of } \\
\text { income }\end{array}$ & 5 & $\begin{array}{l}\text { Higher-income individuals } \\
\text { can donate money to build } \\
\text { infrastructures which } \\
\text { eventually help to increase } \\
\text { the value of attractiveness. }\end{array}$ & \begin{tabular}{|l} 
Mountain museum \\
park, Sarangkot \\
recreation area, \\
Davi's fall, Sarangkot \\
viewpoint, Mahendra \\
cave \\
\end{tabular} \\
\hline 6. & $\begin{array}{l}\text { Increase in } \\
\text { land value } \\
\text { as a result of } \\
\text { rapid increase } \\
\text { in population }\end{array}$ & 2 & $\begin{array}{l}\text { Due to high land value, } \\
\text { people have brought the } \\
\text { land which was previously } \\
\text { left idle resulting decrease } \\
\text { in the area as well as the use } \\
\text { pattern of land ( from idle to } \\
\text { agriculture). }\end{array}$ & $\begin{array}{l}\text { Ramghat, Phewa } \\
\text { wetland }\end{array}$ \\
\hline & $\begin{array}{l}\text { Improvement } \\
\text { in awareness } \\
\text { among local } \\
\text { people and } \\
\text { communities }\end{array}$ & 2 & $\begin{array}{l}\text { As the people realized the } \\
\text { importance of POS, they } \\
\text { carried out activities such as } \\
\text { fencing, gardening, sheds, } \\
\text { foot trek development. As } \\
\text { a result, the area remains } \\
\text { constant and the quality is } \\
\text { improved. }\end{array}$ & $\begin{array}{l}\text { Martyrs park, Thulakot } \\
\text { viewpoint }\end{array}$ \\
\hline 8. & $\begin{array}{l}\text { Increase } \\
\text { in the flow } \\
\text { of both the } \\
\text { international } \\
\text { and domestic } \\
\text { tourists }\end{array}$ & 6 & $\begin{array}{l}\text { Protection and improvement } \\
\text { in the quality of open space } \\
\text { through the development of } \\
\text { service infrastructure and } \\
\text { improving the greener }\end{array}$ & $\begin{array}{l}\text { World Botanical } \\
\text { Garden, World Peace } \\
\text { Pagoda, Khaste lake, } \\
\text { Sita cave, Seti gorge, } \\
\text { KISingh, Jayakot, } \\
\text { Karki Danda } \\
\end{array}$ \\
\hline 9. & $\begin{array}{l}\text { People } \\
\text { perception }\end{array}$ & 2 & $\begin{array}{l}\text { Develop the notion that open } \\
\text { space should be protected } \\
\text { for a sustainable city. }\end{array}$ & $\begin{array}{l}\text { Jaubari Reservoir, } \\
\text { Kamal Pokhari }\end{array}$ \\
\hline
\end{tabular}

Source: Field study, 2018.

The above table shows that 21.87 percent of patches are changed by accelerated urbanization while 18.75 percent patches are made useable for the touristic destination. 
However, among the patches, the infrastructure development in 50 percent and internal layout 34.37 percent patches also bring major pathways to change inside the patches.

From an economic point of view, POS is a living resource of cities. It also helps to generate employment opportunities for the people through management practices and local government to generate income through the ticketing system. Indirectly, patches at a distance of 150 meters to 1000-meter near distance of POS have relatively high land value because of the more opportunities like establishing shop and big complex. Sararngkot viewpoint area, and World Peace Pagoda area, have increased business activities. The economic activities like business practices and income generation play a vital role to change the site. The business activities around the Phewa lake, David's falls, Mahendra cave, Sarangkot viewpoint are comparatively high than other less developed areas of PMC. However, Pradarsani Kendra (exhibition center) has been established from the economic point of view whereas other several exhibitions are also conducted to increase business and economic activities as shown in table 6 .

Table 6: Economic factors

\begin{tabular}{|c|c|c|c|c|}
\hline $\begin{array}{l}\text { Sites of } \\
\text { economic } \\
\text { importance } \\
\end{array}$ & $\begin{array}{l}\text { Visitors } \\
\text { / day }\end{array}$ & \begin{tabular}{|l|} 
Activities related to \\
the change in area and \\
quality of open spaces \\
\end{tabular} & $\begin{array}{l}\text { Source of } \\
\text { income }\end{array}$ & \begin{tabular}{|l} 
Responsible \\
institutions for \\
management \\
\end{tabular} \\
\hline $\begin{array}{l}\text { Mountain } \\
\text { museum park }\end{array}$ & 160 & Gardening and greenery & $\begin{array}{l}\text { Charge to } \\
\text { visitors for use. }\end{array}$ & $\begin{array}{l}\text { Management by } \\
\text { tourism board of } \\
\text { Nepal }\end{array}$ \\
\hline $\begin{array}{l}\text { Sarangkot } \\
\text { recreation area }\end{array}$ & 90 & $\begin{array}{l}\text { Land-use change } \\
\text { i. e construction of } \\
\text { paragliding flight } \\
\text { ground }\end{array}$ & $\begin{array}{l}\text { Charge for } \\
\text { paragliding } \\
\text { expedition. }\end{array}$ & $\begin{array}{l}\text { Individual business } \\
\text { promoter }\end{array}$ \\
\hline Davis' falls & 770 & $\begin{array}{l}\text { Fencing, gardening, } \\
\text { footpath development, } \\
\text { lighting, etc. }\end{array}$ & $\begin{array}{l}\text { Charge entry fee } \\
\text { to visitors. }\end{array}$ & $\begin{array}{l}\text { Management of site } \\
\text { and some portion } \\
\text { provide to the } \\
\text { Chhorepatan high } \\
\text { school }\end{array}$ \\
\hline Phewa lake & 2000 & $\begin{array}{l}\text { Development of service } \\
\text { infrastructure and } \\
\text { other tourism-related } \\
\text { activities such as } \\
\text { boating }\end{array}$ & $\begin{array}{l}\text { Boating fee, } \\
\text { fishing, etc. }\end{array}$ & Boating business \\
\hline $\begin{array}{l}\text { Sarangkot } \\
\text { viewpoint }\end{array}$ & 490 & $\begin{array}{l}\text { Fencing of the } \\
\text { compound, construction } \\
\text { of view tower }\end{array}$ & $\begin{array}{l}\text { Charge entry fee } \\
\text { to visitors. }\end{array}$ & Management who??? \\
\hline
\end{tabular}




\begin{tabular}{|l|l|l|l|l|}
\hline Mahendra cave & 910 & $\begin{array}{l}\text { Lighting, gardening, } \\
\text { construction of footpath } \\
\text { picnic spot, shade etc. }\end{array}$ & $\begin{array}{l}\text { Charge an entry } \\
\text { fee to visitors. }\end{array}$ & $\begin{array}{l}\text { Bindabasini high } \\
\text { school }\end{array}$ \\
\hline Seti gorge park & 55 & $\begin{array}{l}\text { Fencing, gardening, and } \\
\text { construction of, footpath }\end{array}$ & $\begin{array}{l}\text { Charge entry fee } \\
\text { to visitors. }\end{array}$ & $\begin{array}{l}\text { Pokhara metropolitan } \\
\text { city }\end{array}$ \\
\hline $\begin{array}{l}\text { Pradarsni } \\
\text { Kendra }\end{array}$ & $\begin{array}{l}5000 \\
\text { (but not } \\
\text { regular) }\end{array}$ & $\begin{array}{l}\text { Construction of } \\
\text { exhibition hall, parking } \\
\text { area }\end{array}$ & $\begin{array}{l}\text { Charge entry fee } \\
\text { to visitors. }\end{array}$ & $\begin{array}{l}\text { Individual business } \\
\text { promoter }\end{array}$ \\
\hline
\end{tabular}

Source: Field study, 2018.

The table 6 shows that there are number of visitors visiting these sites. The site management committee and government authority charge the fee to enter these site to raise money. However, among the total sites of POS these sites are quite attractive as well as well managed. It is found that, due to their regular income the management body is also inspired to develop required infrastructure development. Therefore, economy generation sites are significantly changed and making these places more attractive.

Pokhara is a city with a large number of followers of the Hindu religion. So several temples dedicated to different gods and goddesses have been built. Apart from Hindus, Buddhists, Christian, and Muslims have also built their religious sites in different parts of the city. Due to spiritual attraction, these sites currently serve as urban public open spaces. Because of their religious beliefs, these sites are found to be protected and infrastructure development works are being carried out with donations and grants. Among the religious sites of POS, Bhadrakali, World Peace Pagoda and Kedareswhwor temple are the main but riverbanks like Ramghat, Tulasi Tara Ghat and Chirgadi Ghat are also occasionally used for religious point of view. Out of the total, almost 18.75 percent patches are used (including holy bathing such as Ramghat, Chirgadi Ghat, Tulasi Tara Ghat) for religious activities.

The metropolitan office prepared urban land use plan along with POS. POS are being used for different purposes as its spatial configurations. However, local policy tries to promote POS as a park, exhibition center, dumping site, religious site, river strip, and recreational area. Basundhara park, Martyr's park, Bhandardhik playground, Bhadrakali religious site, Pradarsani center, dumping site are developed by municipality through local policy while Mountain Museum Park, World Botanical Garden, Pokhara Stadium, World Peace Pagoda have been established and developed by national policy. However, these sites helped to maintain the urban environment and preserved patches of POS contribute to the beautification of the city. 


\section{Conclusion}

Public open space is essential site for urbanization. These sites are continuously transforming into public open space. These sites provide an opportunity to the people and creates pleasant environment around the city. So, this study focuses to explore the pathways and magnitude to change of POS and its driving factors in PMC. The pathways and driving factors are identified through the empirical and field study approach. Public open space is an integral part of city land use. It is public or public area which is basically used for park, playground, religious space, recreational activities and different social and economic purposes. Although, different changes have occurred due to different pathways and driving factors, these sites have great importance, but the data shows that the magnitude of change is dejected. During the last twenty years 13 patches have been shrunk while only one patch area is increased out of total 32 sites.

In general, POS is changed with urbanization, development policies and community interest. In fact, the public open spaces are mosaics of nature. Human managed patches and their driving factors such as natural, socio-economic, religious and government policy play vital role to bring the change. As a result, patches are found in multifold changing patterns. The landscape such as water surface, river strip, cave, and natural vegetation covered area seem to be changing according to the natural process as well as cultural purpose. However, physical-biological factors, socio-economic factors, religious factors, national and local policy are major driving factors to change the external and internal site of POS. Therefore, pathways and magnitude of change of POS are mainly determined by increase and decrease in size, change in land cover, change in use or function, developed infrastructure services and internal layout of patches. This study shows that the POS is going to reduce 0.13 percent area in every year. The water surface, viewpoints, cave, and river strips are mainly changed by natural factors whereas parks, playgrounds, religious sites, and messy space are changed by different pathways and socio-economic driving factors. Similarly, the need for society, site attraction, income capacity of sites also plays a significant role in pathways of change of POS.

All public open space patches in PMC might attribute different spatial configurations. So, to explore their situation further, a detail study is needed. The pathways and magnitude of change and driving factors help further in site design which can contribute to make it more attractive and popular destination to the public open space visitors in urban area. 


\section{References}

Adhikari J. (2004). A social-ecological analysis of the loss of public's properties in an urban environment: A case study of Pokhara, Nepal. Contribution of Nepalese society, 31 (1), 85-114.

Burgi, M., Hersperger, A, \& Schneeberger, N. (2004). Driving forces of landscape change: Current and new directions. Landscape Ecology, 19 (8), 857-868 DOI: 10.1007/s10980-005-0245-3.

Carr, S., Francis, M., Rivlin, L. G. \& Stone, A. M., (1992). Needs of Public Space. Cambridge, UK: Cambridge University Press.

CBS, (2011). National population and housing census, 2011. Kathmandu Nepal: Centre Bureau of Statistics, National planning commission.

Chitrakar, R., M. (2015). Transformation of public space in contemporary urban neighborhoods of Kathmandu valley. Unpublished PhD dissertation: School of civil engineering and built environment, faculty of science and engineering, Queensland University of Technology.

Council of Europe (2000). European landscape convention. Florence (European Treaty Series 176).

Cranz, G. (1982). The Politics of park design: A history of urban parks in America. USA, Massachusetts: The MIT Press, Cambridge.

Duff, C. (2010). On the role of affect and practice in the production of place. Environ Plan. Design. 28 (5), 881-905. Design. Retrieved from

https://www.melbourne.vic.gov.au/SiteCollection Documents/public-spaces.pdf.

Galic, M. (2017). Conceptualization space and place: Lesson from geography for the debate on privacy in public. Retrieved from https://www.researchgate.net/ profile/Masa_Galic2

Ghel, J. (2002). Public space and Public life city of Adelaide: City of Adelaide, Adelaide.

Gold, S. M. (1980). Recreation planning and design, New York: Mc Graw-hill Book company.

MoLRM (2069 BS). Land use policy in Nepal. Kathmandu: Ministry of Land Reform and Management (MoLRM), Shinghdurbar, Kathmandu.

Gurung, H. (1965). Pokhara valley: A geographical survey. University of London: Department of Geography, School of Oriental \& African Studies. 
Kalpan, R. (1985). The analysis of perception via preference: A strategy for studying how the environment is experienced. Landscape Planning, (12), 161-176.

Kong, F. and Nakagoshi, N. (2005). Changes of urban green spaces and their driving forces. Journal of International Development and Cooperation, (Special Issue 2), 97-109.

Lefebvre, H. (1991). The production of space, Trans. Donald Nicholson-Smith, Oxford: Blackwell Publishers.

Madanipour, A. (1999). Why are the design and development public space significant for cities? Environment and Planning B: Planning and Design, 26 (6), 879- 891.

Nasution, A. D. and Zahrah, W. (2012). Public open space's contribution to quality of life: Does privatization matters? Asian Journal of Environment-Behaviors Studies (3), 59-74.

Nasution, A. D. and Zahrah, W (2014). Community perception on public open space and quality of life in medan. Indonesia. Procedia - Social and Behavioral Sciences, (153), $585-594$.

Omar, D. B., Ibrahim, F. 1. B. and Mohamad, N. H. B. (2015). Human interaction in open spaces. Social and Behavioral Sciences, (201), 352-359.

Perovic, S. and Folic, N. K. (2012). Visual perception of public open spaces in Niksic, Social and Behavioral Sciences, (68), 921 - 933.

Pokharel R. P. and Khanal, N. R. (2018). Open space: Typology and distribution in Pokhara Lekhnath Metropolitan city. The Geographical journal of Nepal, (11), 25-44.

Project for Public Spaces (2000). How to turn a place around: A hand book of creating successful public space? New York: Project for Public space.

Rivlin, L. G. (1994). Public space and public life in urban area, In Neary, Sj., Symes, Ms.S., F.E. (eds), The Urban Experience: A people environment perspective (pp 289-298). London: Taylor and Francis Group.

Thompson, W. C. (2002). Urban open space in the $21^{\text {st }}$ century. Landscape and urban planning, (60), 59-72.

Thomas, S. (2008). Urbanization and a driver of change, Transaction on ecology and the environment (117) 94-104. Retrieved from www. witpress.com, ISSN 17433541. 
Ramjee Prasad Pokharel \& Narendra Raj Khanal / Pathways and magnitude... Vol. 13: 143-166, 2020

Tunner II, B. L., Moss, R. H., \& Skole, D. L. (eds) (1993). Relating land use and global land-cover change: Report No. 24, International Geosphere-Biosphere Program, Stockholm.

Urban Task Force (1999). Toward the urban renaissance. London: E \& F. N. Spon.

Villanueva, K., Badland, H., Hooper, P., Koohsri, M. J., Mavoa, S., Davern M., Roberts R., Goldfeld S. \& Corti B. G. (2015). Developing indicators of public open space to promote health and wellbeing in communities, Applied Geography, (57), 112-119.

Walzer, M. (1986). Public space: Pleasures and costs of urbanity. Dissent, (33), 470-475.

Whyte, W. H. (1985). The social life of small urban space. Washington DC: The Conservation Foundation.

Woolley, H. (2003). Urban open spaces. London: Spon Press. 